Journal of Mechanical Engineering and Sciences

ISSN (Print): 2289-4659; e-ISSN: 2231-8380

Volume 12, Issue 4, pp. 4088-4097, December 2018

(C) Universiti Malaysia Pahang, Malaysia

DOI: https://doi.org/10.15282/jmes.12.4.2018.08.0354

\title{
Amine-based carbon dioxide absorption: evaluation of kinetic and mass transfer parameters
}

\author{
S. Ma'mun ${ }^{*}$, Hallvard F. Svendsen ${ }^{2}$, and I M. Bendiyasa ${ }^{3}$ \\ ${ }^{1}$ Department of Chemical Engineering, Faculty of Industrial Technology, \\ Universitas Islam Indonesia \\ J1. Kaliurang Km. 14.5, Yogyakarta 55584, Indonesia \\ Phone: +62274895287; Fax: +62274895007 \\ *Email: sholeh.mamun@uii.ac.id \\ ${ }^{2}$ Department of Chemical Engineering, \\ Norwegian University of Science and Technology, N-7491 Trondheim, Norway \\ ${ }^{3}$ Department of Chemical Engineering, Faculty of Engineering, \\ Universitas Gadjah Mada \\ Jl. Grafika No. 2, Kampus UGM, Yogyakarta, Indonesia 55281
}

\begin{abstract}
Global emission of carbon dioxide $\left(\mathrm{CO}_{2}\right)$, a major contributor to the climate change, has increased annually and it reached over $37 \mathrm{Gt}$ in 2017. An effort to reduce the emission, therefore, needs to be conducted, e.g. post-combustion capture by use of amine-based absorption. The objective of this study is to evaluate the kinetic and mass transfer parameters in a $\mathrm{CO}_{2}$ absorption process using monoethanolamine (MEA), 2(methylamino)ethanol (MMEA), and 2-(ethylamino)ethanol (EMEA) as absorbents. The experiments were conducted in a bubble reactor at atmospheric pressure and $40{ }^{\circ} \mathrm{C}$ with 10 -vol\% $\mathrm{CO}_{2}$ flowrate of $5 \mathrm{NL} / \mathrm{men}$. The $\mathrm{CO}_{2}$ concentration leaving the reactor was measured by an IR $\mathrm{CO}_{2}$ analyzer. The results obtained from this experiment were the overall absorption rates consisting of both chemical reaction and mass transfer. Analysis result shows that the reaction between $\mathrm{CO}_{2}$ and amines takes place fast, therefore the mass transfer of $\mathrm{CO}_{2}$ from the gas into the liquid through the gas film would control the overall absorption rate.
\end{abstract}

Keywords: Kinetics; mass transfer; absorption; carbon dioxide; alkanolamine; bubble reactor

\section{INTRODUCTION}

Global warming phenomenon is mainly caused by greenhouse gas (GHG) emissions, e.g. carbon dioxide $\left(\mathrm{CO}_{2}\right)$, in the atmosphere. The $\mathrm{CO}_{2}$ emission tends to rise annually. In 2010, $\mathrm{CO}_{2}$ emission reached $30 \mathrm{Gt}$ and increased to over $37 \mathrm{Gt}$ in 2017 [1]. Some attempts have been taken to reduce the $\mathrm{CO}_{2}$ emission, such as implementation of $\mathrm{CO}_{2}$ Capture and Storage (CCS) technology. In addition, utilization of natural gas and biomass-based energy may also reduce the $\mathrm{CO}_{2}$ emission [2-6]. Post-combustion capture is one of the $\mathrm{CO}_{2}$ capture technologies in which it can either be built separately or it can also be retrofitted to an existing plant. In this technology, $\mathrm{CO}_{2}$ will be absorbed from a $\mathrm{CO}_{2}$ source such as flue gas stream from a coal-fired power plant. Carbon dioxide absorbed may then be transported into underground geological storage or is utilized for other purposes, e.g. 
Enhanced Oil Recovery (EOR), enhanced coal bed methane, polymer processing, synthetic fuels, mineralization, urea production, dry ice, food and beverage carbonation, and soda ash industry. Recently, $\mathrm{CO}_{2}$ is also utilized for essential oil production using supercritical $\mathrm{CO}_{2}$ extraction process [7-16].

Absorption is the most common process used in the acidic gas removal today. For economic reasons, a low cost and energy-saving absorbent is a must. In addition, a commercial absorbent must offer high absorption rate, high cyclic capacity, low corrosive, good chemical stability, etc. Amine-based $\mathrm{CO}_{2}$ absorption is one of the processes that can be applied to post-combustion capture. This technology has been proven and mature and is still competitive to be developed in the future [17].

This study aims to evaluate kinetic and mass transfer parameters in the amine-based $\mathrm{CO}_{2}$ absorption process. The results obtained from the experiment are the overall absorption rate over time at which the overall absorption rate comprises chemical reactions and mass transfer that took place simultaneously. Furthermore, some approaches were taken so that regimes that control the process could be evaluated. The kinetics of $\mathrm{CO}_{2}$ absorption can, therefore, be predicted which is subsequently used in designing absorber and desorber columns.

Research on the kinetic and mass transfer parameters determination for the aminebased $\mathrm{CO}_{2}$ absorption process was conducted by many researchers using string of discs contactor, wetted wall column, stopped flow technique, stirred cell, square bubble column, etc. [18-27]. The current investigation is important to determine which regimes that control the overall process in a bubble reactor.

\section{Short Review on Kinetic and Mass Transfer Theory}

The amine-based $\mathrm{CO}_{2}$ absorption is considered as a chemical absorption in which a series of mass transfer and chemical reaction equilibria for the $\mathrm{CO}_{2}$ absorption into an aqueous solution of primary alkanolamine are as follows [28, 29]:

Dissolution of $\mathrm{CO}_{2}$ :

$$
\mathrm{CO}_{2(\mathrm{~g})} \leftrightarrow \mathrm{CO}_{2(\mathrm{l})}
$$

Dissociation of water:

$$
2 \mathrm{H}_{2} \mathrm{O} \leftrightarrow \mathrm{H}_{3} \mathrm{O}^{+}+\mathrm{OH}^{-}
$$

Dissociation of $\mathrm{CO}_{2}$ :

$$
\mathrm{CO}_{2(\mathrm{l})}+2 \mathrm{H}_{2} \mathrm{O} \leftrightarrow \mathrm{HCO}_{3}^{-}+\mathrm{H}_{3} \mathrm{O}^{+}
$$

Dissociation of bicarbonate ion:

$$
\mathrm{HCO}_{3}^{-}+\mathrm{H}_{2} \mathrm{O} \leftrightarrow \mathrm{CO}_{3}^{=}+\mathrm{H}_{3} \mathrm{O}^{+}
$$

Dissociation of protonated amine:

$$
\mathrm{AmH}^{+}+\mathrm{H}_{2} \mathrm{O} \leftrightarrow \mathrm{Am}+\mathrm{H}_{3} \mathrm{O}^{+}
$$

Carbamate formation:

$$
\mathrm{Am}+\mathrm{CO}_{2(\mathrm{l})}+\mathrm{H}_{2} \mathrm{O} \leftrightarrow \mathrm{AmCOO}^{-}+\mathrm{H}_{3} \mathrm{O}^{+}
$$

Dissociation of protonated carbamate:

where Am refers to alkanolamine.

$$
{ }^{+} \mathrm{HAmCOO}^{-}+\mathrm{H}_{2} \mathrm{O} \leftrightarrow \mathrm{AmCOO}^{-}+\mathrm{H}_{3} \mathrm{O}^{+}
$$

The amine-based $\mathrm{CO}_{2}$ absorption can be approximated by the two-film theory [30] as shown in Figure 1. Based on this theory, the overall reaction rate for the absorption process by chemical reaction in alkanolamine solution can be written as follows: 


$$
-r_{\mathrm{CO}_{2}}=\frac{1}{\frac{1}{k_{\mathrm{CO}_{2, \mathrm{G}}} a}+\frac{H_{\mathrm{CO}_{2}}}{k_{\mathrm{CO}_{2, \mathrm{~L}}} a E}+\frac{H_{\mathrm{CO}_{2}}}{k C_{\mathrm{Am} f_{\mathrm{L}}}}} p_{\mathrm{CO}_{2}}
$$

where $k_{\mathrm{L}}$ and $k_{\mathrm{G}}$ are the liquid and gas mass transfer coefficients, while $a, k, C, p, H, E$, and $f_{\mathrm{L}}$ are interfacial area, reaction rate constant, concentration, partial pressure, Henry's constant, enhancement factor, and liquid holdup, respectively.

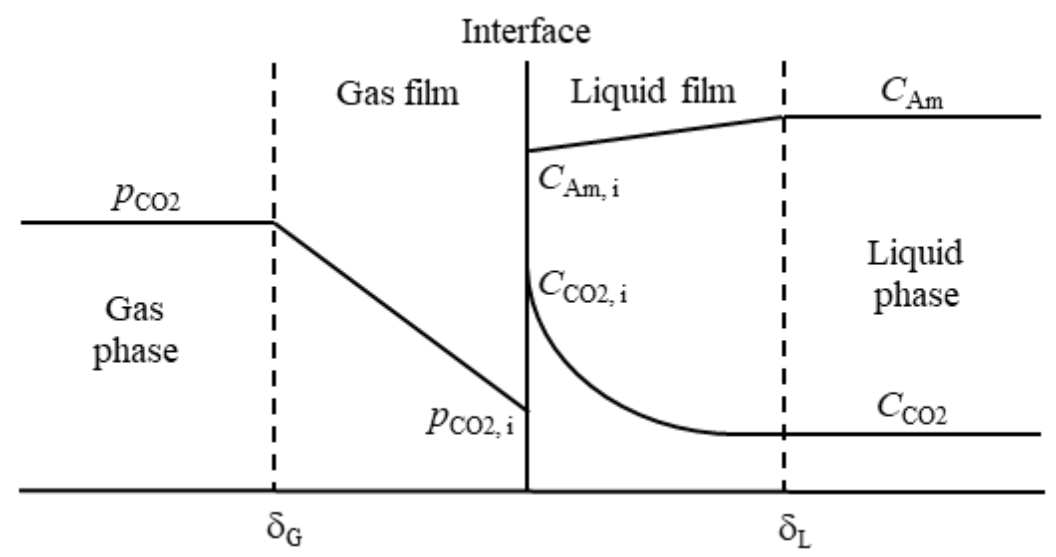

Figure 1. The two-film theory for gas-liquid reaction

In general, for the absorption process carried out by bubbling gas into batch absorbent, the overall reaction rate can be expressed as follows [30]:

$$
-r_{A}=\frac{p_{\mathrm{A}, \mathrm{in}}}{\frac{P V_{\mathrm{r}}}{F_{\mathrm{G}}}+\frac{1}{k_{\mathrm{A}, \mathrm{G}} a}+\frac{H_{A}}{k_{\mathrm{A}, \mathrm{L}} a E}+\frac{H_{A}}{k C_{\mathrm{B}} f_{\mathrm{L}}}}
$$

where $P, V \mathrm{r}$ and $F_{\mathrm{G}}$ are total pressure $(\mathrm{Pa})$, reactor volume $\left(\mathrm{m}^{3}\right)$, and inert gas flowrate $(\mathrm{mol} / \mathrm{s})$, respectively.

\section{MATERIALS AND METHOD}

The purities of $\mathrm{CO}_{2}$ and $\mathrm{N}_{2}$ obtained from AGA Gas $\mathrm{GmbH}$ were 99.99 and $99.6 \mathrm{~mol} \%$, respectively. MEA $\left[\mathrm{H}_{2} \mathrm{~N}\left(\mathrm{CH}_{2}\right)_{2} \mathrm{OH}\right]$, MMEA $\left[\mathrm{CH}_{3} \mathrm{NH}\left(\mathrm{CH}_{2}\right)_{2} \mathrm{OH}\right]$ and EMEA $\left[\mathrm{CH}_{3} \mathrm{CH}_{2} \mathrm{NH}\left(\mathrm{CH}_{2}\right)_{2} \mathrm{OH}\right]$ were obtained from Acros Organics with the reported purities of more than 99, 98, and $99 \mathrm{wt} \%$, respectively.

The absorption rate measurement was carried out in a bubble reactor as shown in Figure 2. Similar apparatus was used by [31] and was then modified by [32] to be capable of desorption measurement. The apparatus equipped with six thermocouples, a water bath, an IR $\mathrm{CO}_{2}$ analyzer, and a mass flow controller is designed to operate at a temperature up to $80^{\circ} \mathrm{C}$ and at atmospheric pressure. Before starting the experiment, the analyzer was first calibrated by a gas mixture of $\mathrm{CO}_{2}-\mathrm{N}_{2}$ with $10 \mathrm{vol} \%$ of $\mathrm{CO}_{2}$ through a by-pass valve. The absorption process begins after the calibration is completed by automatically closing the by-pass valve. At the same time, the $\mathrm{CO}_{2}-\mathrm{N}_{2}$ gas mixture flows through a saturator and to the reactor containing $750 \mathrm{~mL}$ of the absorbent. The gas coming out of the reactor is cooled before entering the IR $\mathrm{CO}_{2}$ analyzer to condense water. The 
absorption process that operates at $40{ }^{\circ} \mathrm{C}$ is terminated after the $\mathrm{CO}_{2}$ concentration coming out of the reactor has reached $9.5 \mathrm{vol} \%$ of $\mathrm{CO}_{2}$ (i.e. $\mathrm{p}_{\mathrm{CO} 2}=9.5 \mathrm{kPa}$ ). Furthermore, a certain amount of liquid was taken for analysis of $\mathrm{CO}_{2}$ content in the liquid phase.

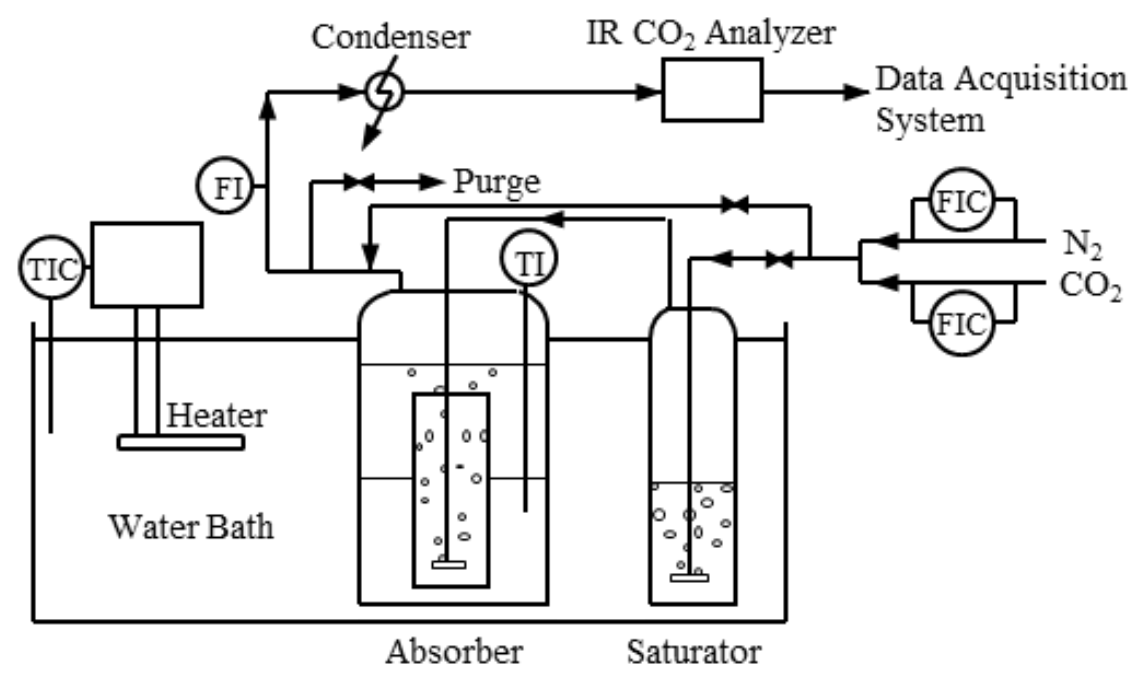

Figure 2. Experimental set up for $\mathrm{CO}_{2}$ absorption measurement

\section{RESULTS AND DISCUSSION}

The $\mathrm{CO}_{2}$ absorption into aqueous solutions of primary amine (MEA) and secondary amines (MMEA and EMEA) was carried out at $40{ }^{\circ} \mathrm{C}$. The concentration of three absorbents used was similar, i.e. $30 \mathrm{wt} \%$. The data obtained in this experiment were the $\mathrm{CO}_{2}$ partial pressures from a stream coming out of the reactor at various times. The absorption rate of $\mathrm{CO}_{2}$ can then be calculated by the following equation:

$$
r_{\mathrm{CO}_{2}}=\frac{1}{V_{1}}\left[n_{\mathrm{CO}_{2}, \text { in }}-\frac{y_{\mathrm{CO}_{2}, \text { out }} n_{\mathrm{N}_{2}}}{\left(1-y_{\mathrm{CO}_{2}, \text { out }}\right)}\right]
$$

where $V_{1}, n$, and $y$ are the liquid volume (L), gas flowrates (mol/s), and the mole fraction. It should be noted that the determination of Rate Determining Step (RDS) is semiquantitative, in the sense that during all experiments there is no guarantee that the gasliquid interfacial area (i.e. the bubble structure) was exactly the same. However, the superficial gas velocity was the same, so any differences would, according to [31], arise mainly due to variations in bubble coalescence properties, interfacial tension, density, and viscosity.

Figure 3 shows the absorption rate of $\mathrm{CO}_{2}$ into aqueous solutions of MEA, MMEA, and EMEA with concentration of $30 \mathrm{wt} \%$ each at various times. It is seen that at the beginning of the process, the absorption rate is still high, such that a significant amount of $\mathrm{CO}_{2}$ is absorbed into the solution resulting in the $\mathrm{CO}_{2}$ partial pressure coming out of the reactor still low. The absorption rate decreases as the time increases. This is followed by the increase of $\mathrm{CO}_{2}$ concentrations both in the gas and liquid phases. It can also be seen from the figure that the absorption rate of $\mathrm{CO}_{2}$ into aqueous solution of MEA is higher than into MMEA and EMEA. In other words, the overall absorption rate of $\mathrm{CO}_{2}$ into the primary amine is higher than into the secondary amine. 


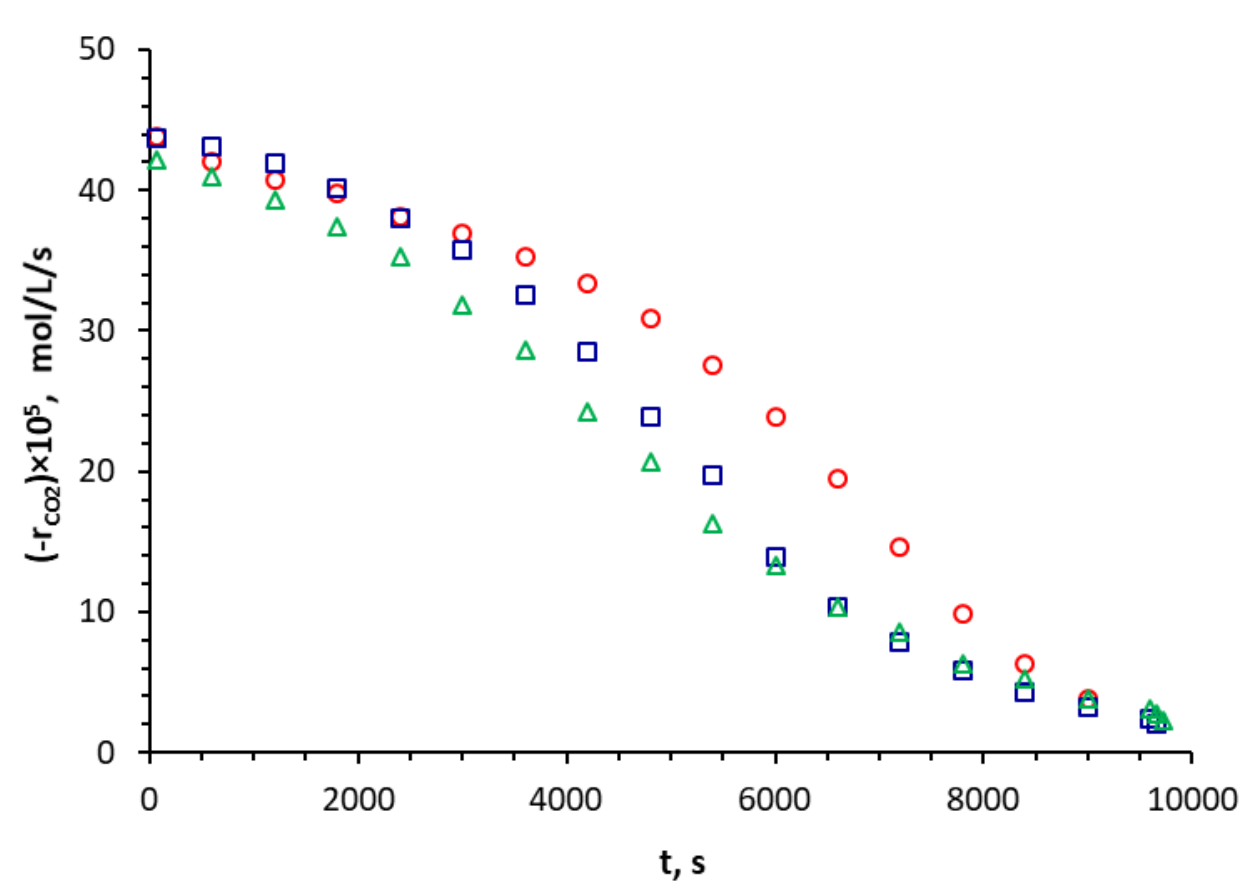

Figure 3. Relationship between the overall absorption rates of $\mathrm{CO}_{2}$ and time at $40{ }^{\circ} \mathrm{C}$ : $\circ, \mathrm{MEA} ; \square$ : MMEA; $\triangle$ : EMEA

It was observed during the experiment that the absorbent was sufficiently mixed in the reactor due to the bubbling of the $\mathrm{CO}_{2}-\mathrm{N}_{2}$ gas mixture. In addition, the circulation of the solution from the bottom up occurs inside the glass sleeve inside the reactor. These conditions make the liquid phase completely mixed, so that it is expected to accelerate the mass transfer of $\mathrm{CO}_{2}$ from gas phase to liquid phase, i.e. the gas and liquid film resistances could be neglected. It can thus be assumed that the reaction in the liquid bulk controls the overall absorption rates. Based on this assumption, Equation (9) can then be simplified into a pseudo-first order reaction:

$$
-r_{\mathrm{A}}=\frac{p_{\mathrm{CO}_{2}, \mathrm{in}}}{\frac{H_{\mathrm{CO}_{2}}}{k C_{\mathrm{Am}} f_{\mathrm{L}}}}=k_{\mathrm{obs}} C_{\mathrm{CO}_{2}}
$$

where $k_{\text {obs }}$ refers to an observed pseudo-first order reaction rate constant. Equation (11) shows a linear relationship between the overall absorption rate and the $\mathrm{CO}_{2}$ concentration in the liquid phase. As seen in Figure 4 that the absorption rate of $\mathrm{CO}_{2}$ into $\mathrm{MEA}$ aqueous solution might fall into a pseudo-first order reaction up to an accumulated $\mathrm{CO}_{2}$ concentration of about $1.43 \mathrm{~mol} / \mathrm{L}$, while for MMEA and EMEA up to 0.75 and 0.71 $\mathrm{mol} / \mathrm{L}$, respectively. The observed pseudo-first order reaction rate constant, $k_{\mathrm{obs}}$, can be determined from the graph of the $\mathrm{CO}_{2}$ absorption rate vs. the $\mathrm{CO}_{2}$ concentration in the liquid phase, where $k_{\mathrm{obs}}$ is the slope of the graph as shown in Figure 5. A similar procedure is then applied to calculate $k_{\text {obs }}$ for the absorption of $\mathrm{CO}_{2}$ into aqueous solutions of MMEA and EMEA, and the results are presented in Table 1.

As seen in Figures 4 and 5 that the pseudo-first order reaction approximation occurs at low $\mathrm{CO}_{2}$ concentrations (i.e. low $\mathrm{CO}_{2}$ loadings). At higher $\mathrm{CO}_{2}$ concentrations, the reaction order in the $\mathrm{CO}_{2}$ might be larger than one. In MEA case, this approach is not in agreement with the zwitterion mechanism as well as the single step - termolecular mechanism. The zwitterion mechanism was first proposed by [33] and reintroduced later 
by [34]. For this mechanism, the reaction between $\mathrm{CO}_{2}$ and amines results a formation of zwitterion intermediate followed by the removal of a proton by a base $\mathrm{B}$. The overall reaction rate can then be expressed as written in Equation (12) by using the pseudosteady-state assumption for the zwitterion concentration.

$$
-r_{\mathrm{CO}_{2}}=\frac{k_{2}^{\mathrm{Z}}\left[\mathrm{R}_{1} \mathrm{R}_{2} \mathrm{NH}\right]\left[\mathrm{CO}_{2}\right]}{1+\frac{k_{-1}}{\sum k_{\mathrm{b}}[\mathrm{B}]}}
$$

If $\left(k_{-1} / \sum k_{\mathrm{b}}[\mathrm{B}]\right) \ll 1$, a simple second-order reaction is obtained and the zwitterion formation is being the RDS, such as MEA in aqueous solutions:

$$
-r_{\mathrm{CO}_{2}}=k_{2}^{\mathrm{Z}}\left[\mathrm{R}_{1} \mathrm{R}_{2} \mathrm{NH}\right]\left[\mathrm{CO}_{2}\right]
$$

where $k_{2}^{\mathrm{Z}}$ is the second-order reaction rate constant for the zwitterion mechanism.

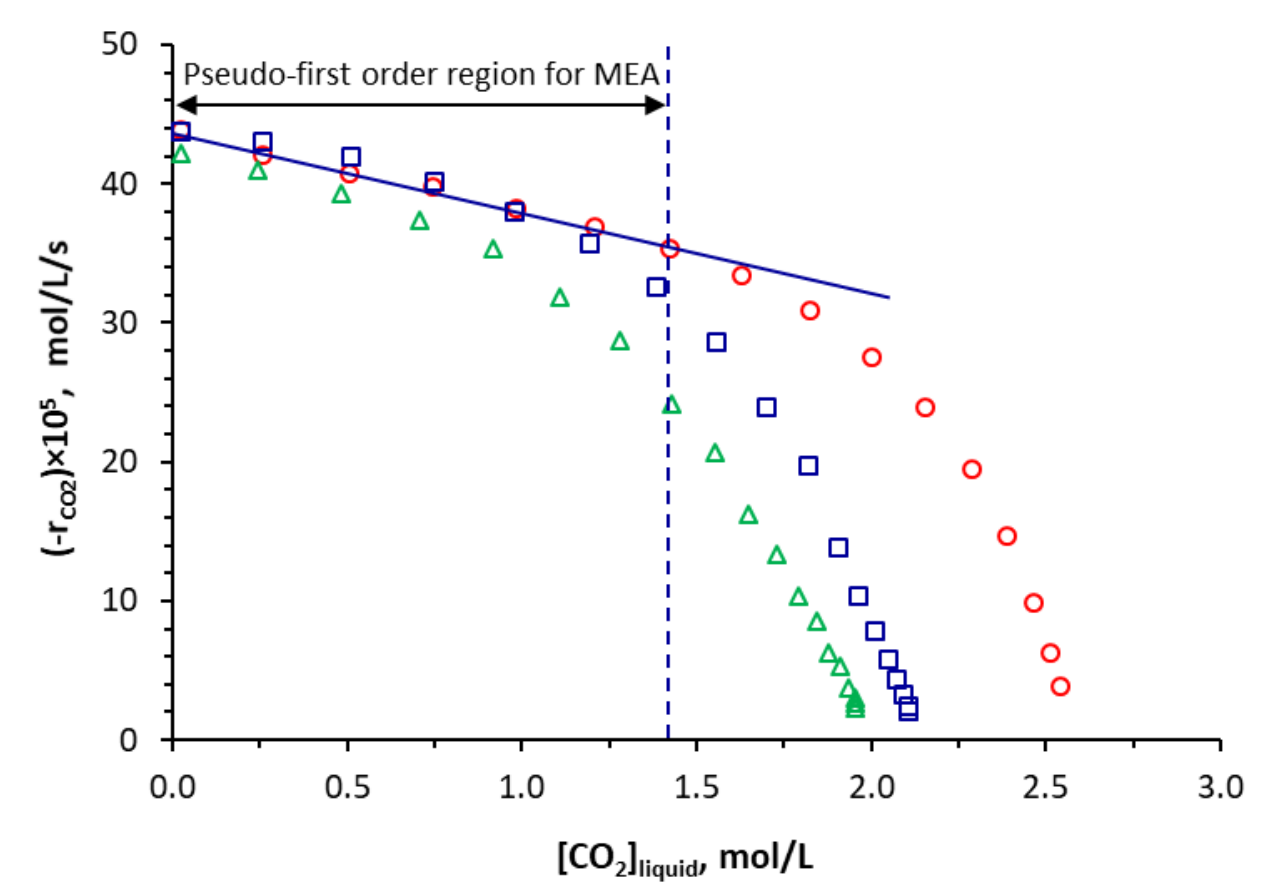

Figure 4. Relationship between the overall absorption rates of $\mathrm{CO}_{2}$ and accumulated $\mathrm{CO}_{2}$ in the liquid phase at $40{ }^{\circ} \mathrm{C}: \circ, \mathrm{MEA} ; \square$ : MMEA; $\triangle$ : EMEA

Based on the zwitterion mechanism, the overall reaction order according to Equation (13) has a value of two and the partial order in the $\mathrm{CO}_{2}$ is equal to one, see [35]. Moreover, based on the single step - termolecular mechanism that was first proposed by [36], the partial order in the $\mathrm{CO}_{2}$ is also equal to one. By applying the zwitterion mechanism, this mechanism proposed that the zwitterion intermediate is formed by assuming that the reaction proceeds through a loosely-bound encounter complex as the initial product, see [37]. The overall reaction rate for this mechanism is defined as follows:

$$
-r_{\mathrm{CO}_{2}}=k_{2}^{\mathrm{T}}\left[\mathrm{R}_{1} \mathrm{R}_{2} \mathrm{NH}\right]\left[\mathrm{CO}_{2}\right]
$$


where $k_{2}^{\mathrm{T}}$ is the second-order reaction rate constant for the single step - termolecular mechanism and is defined as the following:

$$
k_{2}^{\mathrm{T}}=\left\{k_{\mathrm{Am}}\left[\mathrm{R}_{1} \mathrm{R}_{2} \mathrm{NH}\right]+k_{\mathrm{H}_{2} \mathrm{O}}\left[\mathrm{H}_{2} \mathrm{O}\right]+k_{\mathrm{OH}^{-}}\left[\mathrm{OH}^{-}\right]\right\}
$$

According to those two mechanisms, it is obvious that the pseudo-first order reaction approximation in this study might be accepted only at low $\mathrm{CO}_{2}$ loadings, while at high $\mathrm{CO}_{2}$ loadings, the partial order in the $\mathrm{CO}_{2}$ might be larger than one. However, as seen in Table 1 , the $k_{2}$ value for aqueous MEA system is much smaller (i.e., $1.17 \times 10^{-5}$ $\mathrm{L} / \mathrm{mol} / \mathrm{s}$ ) compared to the $k_{2}$ values from [22] which is ranging from about 12 to 50 $\mathrm{L} / \mathrm{mol} / \mathrm{s}$ at the $\mathrm{CO}_{2}$ loadings up to 0.4 and at $41.0{ }^{\circ} \mathrm{C}$. Therefore, it can be concluded that the gas and liquid film resistances cannot be neglected for the bubble reactor. In the present work, bubbling the gas mixture and gas-liquid circulation inside the glass sleeve inside the reactor is not sufficient to get the system well mixed. To reduce the gas and liquid film resistances, one may use multiple stirrers both for liquid and gas phases [18].

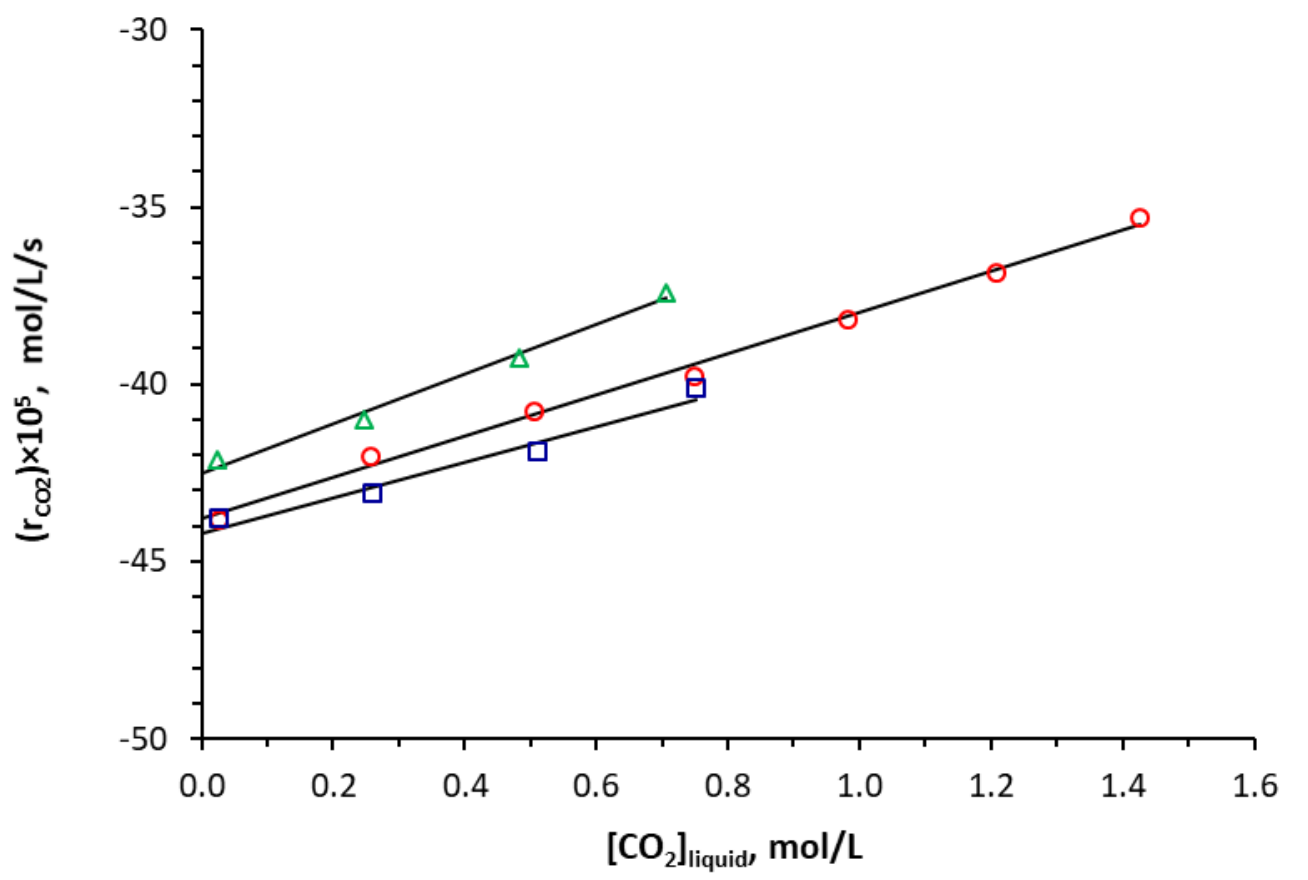

Figure 5. Pseudo-first order reaction approximation of the $\mathrm{CO}_{2}$ absorption into aqueous solution of alkanolamines at $40{ }^{\circ} \mathrm{C}$ : $\circ$, MEA; $\square$ : MMEA; $\triangle$ : EMEA

Table 1. Pseudo-first and second order reaction rate constants

\begin{tabular}{cccccc}
\hline & $k_{\text {obs }} \times 10^{5}, 1 / \mathrm{s}$ & \multicolumn{3}{c}{$k_{2} \times 10^{5}, \mathrm{~L} /(\mathrm{mol} . \mathrm{s})$} \\
\hline MEA & MMEA & EMEA & MEA & MMEA & EMEA \\
\hline 5.84 & 5.03 & 6.97 & 1.17 & 1.17 & 1.94 \\
\hline
\end{tabular}

From the $k_{2}$ value of MEA obtained in this study and that obtained from [22], it is clearly seen that the reaction between $\mathrm{CO}_{2}$ and MEA took place fast, therefore the $\mathrm{CO}_{2}$ mass transfer from the gas bulk to the liquid through the gas film might control the overall absorption rate. Since $1 /\left(k_{\mathrm{A}, \mathrm{G}} a\right) \gg\left[\left(P V_{\mathrm{r}}\right) / F_{\mathrm{G}}+H_{\mathrm{A}} /\left(k_{\mathrm{A}, \mathrm{L}} a E\right)+H_{\mathrm{A}} /\left(k C_{\mathrm{B}} f_{\mathrm{L}}\right)\right]$, Equation (9) can then be simplified into: 


$$
-r_{\mathrm{CO}_{2}}=k_{\mathrm{CO}_{2, \mathrm{G}}} a p_{\mathrm{CO}_{2, \text { in }}}
$$

where $k_{\mathrm{CO}_{2, \mathrm{G}}} a$ refers to the volumetric mass transfer coefficient of $\mathrm{CO}_{2}$ in the gas phase.

\section{CONCLUSION}

The $\mathrm{CO}_{2}$ absorption rate into aqueous solutions of MEA, MMEA, and EMEA with concentration of $30 \mathrm{wt} \%$ each were measured in a bubble reactor at $40{ }^{\circ} \mathrm{C}$. The results show that the absorption rate of $\mathrm{CO}_{2}$ into aqueous solution of MEA is relatively higher than into MMEA and EMEA. Moreover, the $k_{2}$ value for the $\mathrm{CO}_{2}-\mathrm{MEA}-\mathrm{H}_{2} \mathrm{O}$ system obtained in the present study is much smaller $\left\{\right.$ i.e., $\left.1.17 \times 10^{-5} \mathrm{~L} /(\mathrm{mol} . \mathrm{s})\right\}$ in comparison to the $k_{2}$ value for similar system obtained from the literature $\{$ i.e., 12 to $50 \mathrm{~L} /(\mathrm{mol} . \mathrm{s})\}$. Based on this condition, the reaction between $\mathrm{CO}_{2}$ and those aqueous solutions took place fast. The $\mathrm{CO}_{2}$ mass transfer from the gas bulk to the liquid through the gas film might, therefore, control the overall absorption rate.

\section{REFERENCES}

[1] International Energy Agency. World Energy Outlook 2017. Paris: OECD/IEA; 2018.

[2] Gharehghani A, Hosseini R, and Yusaf T. Investigation of the effect of additives to natural gas on heavy-duty SI engine combustion characteristics. Journal of Mechanical Engineering and Sciences. 2013;5:677-87.

[3] Said NH, Ani FN, Said MFM. Review of the production of biodiesel from waste cooking oil using solid catalysts. Journal of Mechanical Engineering and Sciences. 2015;8:1302-11.

[4] Bhaskar K, Sendilvelan S, Muthu V, Aravindraj S. Performance and emission characteristics of compression ignition engine using methyl ester blends of jatropha and fish oil. Journal of Mechanical Engineering and Sciences. 2016;10(2):1994-2007.

[5] Inayat M, Sulaiman SA, Kumar A, Guangul FM. Effect of fuel particle size and blending ratio on syngas production and performance of co-gasification. Journal of Mechanical Engineering and Sciences. 2016;10(2):2187-99.

[6] Bhaskar K, Sendilvelan S. Experimental studies on the performance and emission characteristics of a compression ignition engine fuelled with jatropha oil methyl ester. Journal of Mechanical Engineering and Sciences. 2018;12(1):3431-50.

[7] Aladić K, Jarni K, Barbir T, Vidović S, Vladić J, Bilić M, Jokić S. Supercritical $\mathrm{CO}_{2}$ extraction of hemp (Cannabis sativa L.) seed oil. Industrial Crops and Products. 2015;76:472-78.

[8] Mouahid A, Dufour C, Badens E. Supercritical $\mathrm{CO}_{2}$ extraction from endemic Corsican plants; comparison of oil composition and extraction yield with hydrodistillation method. Journal of $\mathrm{CO}_{2}$ Utilization. 2017;20:263-73.

[9] Zekovic Z, Bera O, Đurovic S, Pavlic B. Supercritical fluid extraction of coriander seeds: kinetics modelling and ANN optimization. The Journal of Supercritical Fluids. 2017;125:88-95. 
[10] Conde-Hernández LA, Espinosa-Victoria JR, Guerrero-Beltrán JA. Supercritical extraction of essential oils of Piper auritum and Porophyllum ruderale. The Journal of Supercritical Fluids. 2017;127:97-102.

[11] Favareto R, Teixeira MB, Soares FAL, Belisário CM, Corazza ML, Cardozo-Filho L. c2017. Study of the supercritical extraction of Pterodon fruits (Fabaceae). The Journal of Supercritical Fluids. 2017;128:159-65.

[12] Lima MA, Charalampopoulos D, Chatzifragkou A. Optimisation and modelling of supercritical $\mathrm{CO}_{2}$ extraction process of carotenoids from carrot peels. The Journal of Supercritical Fluids. 2018;133:94-102.

[13] Benito-Román O, Rodríguez-Perrino M, Sanz MT, Melgosa R, Beltrán S. Supercritical carbon dioxide extraction of quinoa oil: Study of the influence of process parameters on the extraction yield and oil quality. The Journal of Supercritical Fluids. 2018;139:62-71.

[14] Mouahid A, Bouanga H, Crampon C, Badens E. Supercritical $\mathrm{CO}_{2}$ extraction of oil from Jatropha curcas: An experimental and modelling study. The Journal of Supercritical Fluids. 2018;141:2-11.

[15] Frohlich PC, Santos KA, Palú F, Cardozo-Filho L, Silva C, Silva EA. Evaluation of the effects of temperature and pressure on the extraction of eugenol from clove (Syzygium aromaticum) leaves using supercritical $\mathrm{CO}_{2}$. The Journal of Supercritical Fluids. 2019;143:313-20.

[16] Belbaki A, Louaer W, Meniai AH. Supercritical $\mathrm{CO}_{2}$ extraction of oil from crushed Algerian olives. The Journal of Supercritical Fluids. 2017; 130: 165-71.

[17] Ma'mun S. Solubility of carbon dioxide in aqueous solution of potassium sarcosine from 353 to 393K. Energy Procedia. 2014;51:191-6.

[18] Jiru Y, Eimer DA. A study of mass transfer kinetics of carbon dioxide in (monoethanolamine + water) by stirred cell. Energy Procedia. 2013; 37: 2180 - 87.

[19] Monteiro JGMS, Pinto DDD, Luo X, Knuutila H, Hussain S, Mba E, Hartono A, Svendsen HF. Activity-based kinetics of the reaction of carbon dioxide with aqueous amine systems. Case studies: MAPA and MEA. Energy Procedia. 2013;37:1888-96.

[20] Kierzkowska-Pawlak H, Chacuk A, Siemieniec M. Reaction kinetics of $\mathrm{CO}_{2}$ in aqueous 2-(2-aminoethylamino)ethanol solutions using a stirred cell reactor. International Journal of Greenhouse Gas Control. 2014;24:106-14.

[21] Kierzkowska-Pawlak $\mathrm{H}$. Kinetics of $\mathrm{CO}_{2}$ absorption in aqueous N,Ndiethylethanolamine and its blend with $\mathrm{N}$-(2-aminoethyl)ethanolamine using a stirred cell reactor. International Journal of Greenhouse Gas Control. 2015;37:7684.

[22] Luo X, Hartono A, Hussain S, Svendsen HF. Mass transfer and kinetics of carbon dioxide absorption into loaded aqueous monoethanolamine solutions. Chemical Engineering Science. 2015;123:57-69.

[23] Lv B, Sun C, Liu N, Li W, Li S. Mass transfer and kinetics of $\mathrm{CO}_{2}$ absorption into aqueous monoethanolamine/1-hydroxyethy-3-methyl imidazolium glycinate solution. Chemical Engineering Journal. 2015;280:695-702.

[24] Benamor A, Al-Marri MJ, Khraisheh M, Nasser MS, Tontiwachwuthikul P. Reaction kinetics of carbon dioxide in aqueous blends of Nmethyldiethanolamine and glycine using the stopped flow technique. Journal of Natural Gas Science and Engineering. 2016;33:186-95.

[25] Garcia M, Knuutila HK, Gu S. Determination of kinetics of $\mathrm{CO}_{2}$ absorption in unloaded and loaded DEEA+MAPA blend. Energy Procedia. 2017; 114: 1772-84. 
[26] García-Abuín A, Gómez-Díaz D, Navaza, JM, Rumbo A. Carbon dioxide capture with tertiary amines. Absorption rate and reaction mechanism. Journal of the Taiwan Institute of Chemical Engineers. 2017;80:356-62.

[27] Liu B, Luo X, Gao H, Idem R, Tontiwachwuthikul P, Olson W, Liang Z. Reaction kinetics of the absorption of carbon dioxide $\left(\mathrm{CO}_{2}\right)$ in aqueous solutions of sterically hindered secondary alkanolamines using the stopped-flow technique. Chemical Engineering Science. 2017;170:16-25.

[28] Ma'mun S, Jakobsen JP, Svendsen HF, Juliussen O. Experimental and modeling study of the solubility of carbon dioxide in aqueous 30 mass \% 2-((2aminoethyl)amino)ethanol solution. Industrial \& Engineering Chemistry Research. 2006;45:2505-12.

[29] Ma'mun S, Kamariah, Sukirman, Kurniawan D, Amelia E., Rahmat V, Alwani DR. Determination of monoethanolamine protonation constant and its temperature dependency. MATEC Web of Conferences. 2017;1010:02001.

[30] Levenspiel O. (1999). Chemical Reaction Engineering, 3rd ed., New York: John Wiley \& Sons.

[31] Ma'mun S, Svendsen HF, Hoff KA, Juliussen O. Selection of new absorbents for carbon dioxide capture. Energy Conversion and Management. 2007; 48: 251-8.

[32] Aronu UE, Ciftja AF, Kim I, Hartono A. Understanding precipitation in amino acid salt systems at process conditions. Energy Procedia. 2013;37:233-40.

[33] Caplow M. Kinetics of carbamate formation and breakdown. Journal of the American Chemical Society. 1968;90:6795-803.

[34] Danckwerts PV. The reaction of $\mathrm{CO}_{2}$ with ethanolamines. Chemical Engineering Science. 1979;34:443-46.

[35] Versteeg GF, Van Swaaij WPM. On the kinetics between CO2 and alkanolamines both in aqueous and non-aqueous solutions -1 . Primary and secondary amines. Chemical Engineering Science. 1988;43(3):573-85.

[36] Crooks JE, Donnellan JP. Kinetics and mechanism of the reaction between carbon dioxide and amines in aqueous solution. Journal of the Chemical Society, Perkin Transactions II. 1989;331-3.

[37] Ma'mun S, Dindore VY, Svendsen HF. Kinetics of the reaction of carbon dioxide with aqueous solutions of 2-((2-aminoethyl)amino)ethanol. Industrial \& Engineering Chemistry Research. 2007;46:385-94. 